\title{
IMPACT OF SERVICE QUALITY ON RESIDENTIAL SATISFACTION: A STUDY WITH SPECIAL ATTENTION TO CHENNAI
}

\author{
Dr. K. Chezhiyan $1 \bowtie$ \\ ${ }^{1}$ Assistant Professor, Department of Business Administration, Government Arts and Science College, \\ Veppanthattai, Perambalur, India
}

Received 3 September 2021

Accepted 18 September2021

Published 30 September2021

\section{CorrespondingAuthor}

Dr. K. Chezhiyan,

assistantprofessor.au@gmail.com

DOI

10.29121/granthaalayah.v9.i9.2021. 4148

Funding: This research received no specific grant from any funding agency in the public, commercial, or not-for-profit sectors.

Copyright: (C) 2021 The Author(s). This is an open access article distributed under the terms of the Creative Commons Attribution License, which permits unrestricted use, distribution, and reproduction in any medium, provided the original author and source are credited.

\section{ABSTRACT}

The purpose of this paper is to reveal the residential satisfaction of apartment residents. And it was measured through an antecedent (service quality) and a consequence (word of mouth) of residential satisfaction. Simple random sampling method was employed on 200 residents and multiple linear regressions were carried out. The result shows that $85 \%$ of the variance in overall customer satisfaction is accounted for by service quality. From the above findings it is clear that service quality positively influences customer satisfaction.

Keywords: Residential Satisfaction, Apartment Service Quality, House Buying Behavior, Service Quality

\section{INTRODUCTION}

The home-building industry faces challenges in slower economies, and the burden is on home builders to persuade consumers to purchase homes in a buyer's market characterized by high inventory, low consumer confidence in real estate and potential credit difficulties. As market pressures increase and home buyers become better informed, builders are realizing the need to redesign their business strategy to remain competitive (Kerber, 2000).

Most new homes already include a wide variety of innovative features, which leaves only quality of service to set a builder apart from others offering similar homes in similar markets. Large builders of new home construction typically have internal sales personnel that play the role of the real estate agent. These real estate agents represent the builder and they are the first point of contact for potential home buyers. Thus, home builders face a critical challenge the need to thoroughly understand and define home buyers' needs for highquality service, to better prepare their personnel. Regrettably, many home builders do not recognize this need, and their present business processes do not support it (NAHB, 2003).

Some kind of real estate businesses include Professional valuation services, assisting buyers and sellers in transactions, improving land for use by adding or replacing buildings, managing a property for its owner(s), Managing the sale side of the property business, and Relocating people or business to difficult country. 


\section{1) PREVIOUS EVIDENCE REGARDING RESIDENTIAL SATISFACTION}

Many researchers have carried out about the residential satisfaction with apartment industry Balathandayutham and Sritharan (2012), Balathandayutham and Sritharan (2013)a, Balathandayutham and Sritharan (2013)b, Balathandayutham and Sritharan (2013)c, Balathandayutham and Sritharan (2013)d, Balathandayutham and Sritharan (2014)a, Balathandayutham and Sritharan (2014)b, Balathandayutham and Anandanatarajan (2019), apartment satisfaction Balathandayutham and Sritharan (2014), Balathandayutham (2017), Balathandayutham (2019), customer satisfaction in apartment Balathandayutham (2017), Balathandayutham (2018), real estate marketing Balathandayutham and Sritharan (2012), Balathandayutham and Sritharan (2013).

\section{2) PREVIOUS EVIDENCE REGARDING SERVICE QUALITY OF BANKS}

Vethirajan (2016), Vethirajan (2017), Vethirajan (2018)a, Vethirajan (2018)b, Vethirajan (2018)c, Vethirajan (2018)d, Ramu, C., Vethirajan, C, 2019; Madavan and Vethirajan (2019), Madavan and Vethirajan (2020). service quality of health care Vidhya and Rajakumar (2014), Vidhya and Rajakumar (2015), Rajakumar and Anandanatarajan (2008),2019).

\section{REVIEW OF LITERATURE}

Parasuraman et al. (1988) had made a study on a 22-item instrument called SERVQUAL for assessing customer perceptions of service quality in service and retailing organizations. The purpose of this article is twofold 1) to describe the development of a multiple-item scale for measuring service quality (SERVQUAL) and 2) to discuss the scale's properties and potential applications. Data were collected from 200 adult respondents of a large metropolitan area in the SouthWest. A two-part questionnaire consisting of 97 statement expectations were self administered by respondents followed by 97 statement perceptions. Cronbach's coefficient alpha was utilized. ANOVA were also conducted. The results indicate that SERVQUAL can help a wide range of service and retailing organizations in assessing consumer's expectations about and perceptions of service quality. This study will stimulate further studies on antecedents and consequences of service quality.

Noorsidi (2008) has made a study on service quality in high rise building. This study has been undertaken in an apartment in a view to find out the unsatisfactory factors of residents in terms of resident's perceptions. Questionnaire was adopted which focused on two measures of expectations and perceptions of performance. Out of the total of 120 questionnaires, only 85 useable questionnaires were returned. Cronbach's coefficient alpha was utilized to check the internal consistency of tangibility, reliability, assurance, responsiveness and empathy. The result shows that firms should examine five dimensions of service quality to find out the level of service provided, and to find which dimension needs improvement. Further research needs to advance the understanding of the concept and the means to measure and improve service quality.

As stated by Karl (1998) examined the buying behavior of home buyers in the market. The survey has been conducted in four markets which were Anaheim, San Francisco, Boston and Milwaukee. People seem to form their expectations on the basis of past price movements rather than any knowledge of fundamentals. And also stated that home buying was still puzzling market. 
Isabelina Nahmens (2009), observed the customer satisfaction with service quality and home-buyer expectations and their perceptions of service quality. The target groups of his study were buyers of single-family houses built during calendar year 2001 in five counties in central Florida and data collected on late June 2003 and lasted until August 2003. Under the single-family group, they have selected randomly 150 samples. Researcher has identified five dimensions of service quality namely appearance, reliability, timeliness, knowledge and empathy. It is observed that the influence of these variables on customer satisfaction with service quality can positively impact home builders through improved reputation and increased local referrals.

\section{RESEARCH METHODOLOGY}

Research of this study was conducted on data collected from Chennai. The aim of this paper is twofold 1) identifying the relationship between service quality and customer satisfaction and 2) identifying the relationship between customer satisfaction and word of mouth. 22 -item SERVQUAL instrument evolved by Parasuraman et al. (1988) was adopted to find out the inter relationship between dimensions of service quality and customer satisfaction. Word of mouth was measured using a scale developed by Babin, Lee, Kim and Griffin, (Babin et al., 2005). Word of mouth had three statements and these statements were assessed on a 5point likert scale. Chennai metropolitan was the area of research of this study. Simple random sampling method was employed on a sample of 200 apartment residents.

\section{ANALYSIS AND INTERPRETATION}

\begin{tabular}{|cccccc}
\hline \multicolumn{5}{|c}{ Relationship between service quality and customer satisfaction } \\
\hline Model & R & R Square & Adjusted R Square & F & Sig. \\
1 & $.922($ a) & 0.85 & 0.831 & 45.517 & .000 (a) \\
\hline
\end{tabular}

a. Dependent Variable: overall satisfaction

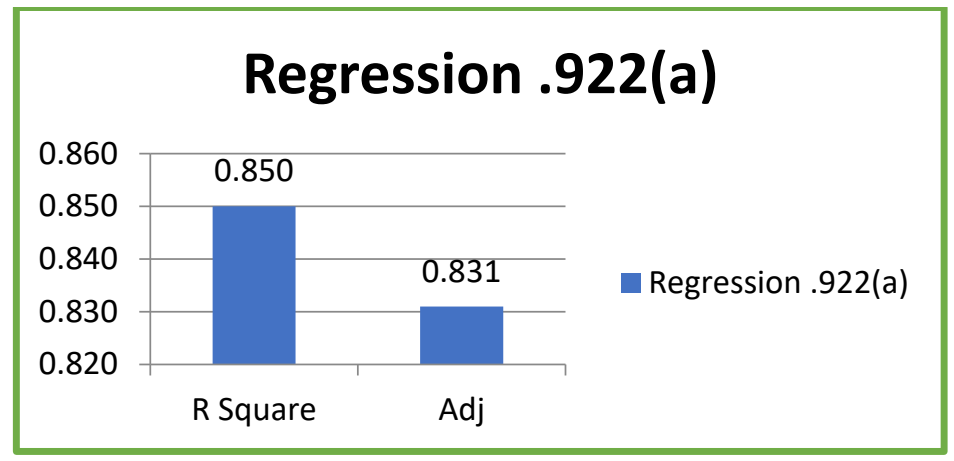

This table provides the Multiple Correlation $(\mathrm{R}=0.922)$, the Multiple Correlation squared $\left(\mathrm{R}^{2}=0.850\right)$, the adjusted Multiple Correlation squared (adj. $\mathrm{R}^{2}$ $=0.831$ ), and the Standard Error of the Estimate. The multiple correlations refer to the combined correlation of each predictor with the outcome. The multiple correlations squared represent the amount of variance in the outcome which is accounted for by the predictors; here, $85 \%$ of the variance in overall customer satisfaction is accounted for by all service quality. However, the multiple correlation squared is a bit optimistic, and therefore, the adjusted $\mathrm{R}^{2}$ is more appropriate. 
The ANOVA summary table indicates that our model's $\mathrm{R}^{2}$ is significantly different from zero, $\mathrm{F}(22,177)=45.517, \mathrm{p}<.001$.

\begin{tabular}{|c|c|c|c|c|c|c|}
\hline \multicolumn{7}{|c|}{ Coefficients } \\
\hline \multirow{2}{*}{\multicolumn{2}{|c|}{ Model }} & \multicolumn{2}{|c|}{$\begin{array}{l}\text { Unstandardized } \\
\text { Coefficients }\end{array}$} & \multirow{2}{*}{$\begin{array}{c}\text { Std } \\
\text { Coefficients } \\
\text { Beta }\end{array}$} & \multirow[t]{2}{*}{$\mathbf{t}$} & \multirow[t]{2}{*}{ Sig. } \\
\hline & & B & $\begin{array}{l}\text { Std. } \\
\text { Error }\end{array}$ & & & \\
\hline & (Constant) & 1.270 & 0.107 & & 11.843 & 0.000 \\
\hline 1 & $\begin{array}{l}\text { All the flats in this apartment should } \\
\text { have up-to-date equipment }\end{array}$ & -0.159 & 0.075 & -0.617 & -2.117 & 0.036 \\
\hline 2 & $\begin{array}{c}\text { Facilities in flats should be visually } \\
\text { appealing. }\end{array}$ & -0.076 & 0.073 & -0.296 & -1.037 & 0.301 \\
\hline 3 & $\begin{array}{c}\text { Promoter's employees should have a } \\
\text { neat dress code }\end{array}$ & 0.008 & 0.027 & 0.030 & 0.307 & 0.759 \\
\hline 4 & $\begin{array}{l}\text { Materials used by the promoter for the } \\
\text { physical facilities should be in a good } \\
\text { appearance. }\end{array}$ & -0.027 & 0.032 & -0.102 & -0.848 & 0.398 \\
\hline 5 & $\begin{array}{c}\text { Delivery of the services should be } \\
\text { prompt. }\end{array}$ & 0.205 & 0.085 & 0.797 & 2.416 & 0.017 \\
\hline 6 & $\begin{array}{l}\text { When purchaser have problem, they } \\
\text { should be sympathetic and reassuring. }\end{array}$ & 0.028 & 0.037 & 0.118 & 0.748 & 0.456 \\
\hline 7 & Promoters should be dependable & -0.044 & 0.030 & -0.172 & -1.474 & 0.142 \\
\hline 8 & $\begin{array}{l}\text { Promoters should provide their } \\
\text { services at the time they promise to do } \\
\text { so. }\end{array}$ & -0.030 & 0.026 & -0.127 & -1.145 & 0.254 \\
\hline 9 & $\begin{array}{l}\text { They should keep their records } \\
\text { accurately. }\end{array}$ & -0.989 & 0.132 & -4.11 & -7.518 & 0.000 \\
\hline 10 & $\begin{array}{c}\text { Promoters shouldn't be informing the } \\
\text { clients as when the services will be } \\
\text { performed. (-) }\end{array}$ & 0.070 & 0.049 & 0.289 & 1.445 & 0.150 \\
\hline 11 & $\begin{array}{l}\text { Employees of the promoter shouldn't } \\
\text { provide prompt service. (-) }\end{array}$ & -0.085 & 0.043 & -0.351 & -1.963 & 0.051 \\
\hline 12 & $\begin{array}{c}\text { Promoter's employees shouldn't always } \\
\text { be willing to help you. (-) }\end{array}$ & 1.346 & 0.133 & 5.630 & 10.116 & 0.000 \\
\hline 13 & $\begin{array}{c}\text { Promoter's employees shouldn't always } \\
\text { be busy to respond to clients requests } \\
\text { promptly (-) }\end{array}$ & -0.082 & 0.043 & -0.344 & -1.901 & 0.059 \\
\hline 14 & $\begin{array}{l}\text { Purchaser should be able to trust } \\
\text { employees of the promoters }\end{array}$ & 0.249 & 0.047 & 1.033 & 5.342 & 0.000 \\
\hline 15 & $\begin{array}{l}\text { Purchaser should be able to feel safe in } \\
\text { their transactions with the promoter's } \\
\text { employees. }\end{array}$ & 0.072 & 0.036 & 0.315 & 2.030 & 0.044 \\
\hline 16 & Promoter's employees should be polite. & -0.089 & 0.026 & -0.378 & -3.446 & 0.001 \\
\hline 17 & $\begin{array}{l}\text { Promoter's employees should get } \\
\text { adequate help from their employer to } \\
\text { help clients. }\end{array}$ & -0.985 & 0.082 & -5.129 & 11.958 & 0.000 \\
\hline 18 & $\begin{array}{l}\text { Individual attention shouldn't be given } \\
\text { to all the clients by the promoter and } \\
\text { his employees. (-) }\end{array}$ & 0.472 & 0.062 & 2.897 & 7.636 & 0.000 \\
\hline 19 & $\begin{array}{l}\text { Employees of promoters should give } \\
\text { personal attention to a specific client. }\end{array}$ & -0.428 & 0.060 & -1.780 & -7.130 & 0.000 \\
\hline 20 & $\begin{array}{l}\text { Employees of the promoter shouldn't } \\
\text { be aware of the needs of the clients. (-) }\end{array}$ & 1.139 & 0.105 & 4.974 & 10.853 & 0.000 \\
\hline & $\begin{array}{l}\text { Promoter's employees shouldn't extend } \\
\text { a true hearted service to their clients. (- }\end{array}$ & -0.087 & 0.035 & -0.149 & -2.490 & 0.014 \\
\hline & $\begin{array}{l}\text { Office hours of the promoter shouldn't } \\
\text { be convenient for the clients. (-) }\end{array}$ & -0.027 & 0.036 & -0.097 & -0.748 & 0.455 \\
\hline
\end{tabular}


Let's focus on the 22 predictors, whether they are statistically significant and, if so, the direction of the relationship. most of the service quality are significant, and the coefficient is positive which would indicate that 12 service qualities are related to higher customer satisfaction. This is what we would expect. The percentage of customer satisfaction with rest of the service quality seems to be not significant. This result also makes sense. Finally, the reliability value of Cronbach's Alpha .603 shown in this study was all more than 0.6 , the constructs were therefore deemed to have adequate reliability. This would seem to indicate that the percentage of customer satisfaction with service quality is an important factor in predicting customer satisfaction

\section{FINDINGS}

The result shows that $85 \%$ of the variance in overall customer satisfaction is accounted for by service quality. From the above findings it is clear that service quality positively influences customer satisfaction. Service quality alone are not enough to judge the residential satisfaction. Several factors were left out for research as untouched which needs to be done in future researches. So, future researches can be done on accessibility issues of apartments.

\section{REFERENCES}

Anandanatarajan, K., (2012) "Antecedent and consequences of service quality in hotel industry - A guest perspective", in Dholy Grace Management Review 4 (1), 87 - 94.

Balathandayutham, P., (2016), "A study on antecedent and consequences of customer satisfaction in apartment culture at Chennai," International Journal of Management Studies, Vol-III, Issue-1, February 2016 , 129-139, 2016.

Retrieved

from

https://www.researchgate.net/profile/Balathandayutham-Dr-

P/publication/342834720_International_Journal_of_Management_Studies_ A_STUDY_ON_ANTECEDENT_AND_CONSEQUENCES_OF_CUSTOMER_SATIS FACTION_IN_APARTMENT_CULTURE_AT_CHENNAI_Introduction/links/5f 085826299bf1881610395f/International-Journal-of-Management-StudiesA-STUDY-ON-ANTECEDENT-AND-CONSEQUENCES-OF-CUSTOMERSATISFACTION-IN-APARTMENT-CULTURE-AT-CHENNAI-Introduction.pdf

Balathandayutham, P., (2017), "A study on perceived risk of residential construction companies and its customers", International Journal of Management Studies, Vol-IV, Issue-1, June 2017, 181 -186.

Balathandayutham, P., (2019), "Influence of apartment price on residential satisfaction: a study in Chennai", International journal of research in computer application \& management, volume no. 9, issue no. 11, November 2019, 5-7.

Balathandayutham, P., Anandanatarajan, K., Sritharan, R., (2012), "Brand Preference in Indian FMCG Industries: An Emprical Study", INDIFED, Symposium, Chennai, 2012.

Balathandayutham, P., Anandanatarajan, K., (2019) "Price and Green Attitude Towards Environmental Friendly Product in Chidambaram", Review of Research Journal, Special Issue Volume 1 November, Page 226-231. Retrieved

from _ATTITUDE_TOWARDS_ENVIRONMENTAL_FRIENDLY_PRODUCT_IN_CHID 
AMBARAM20200710-43745-kk37yz-with-cover-page-

v2.pdf?Expires $=1634283445 \&$ Signature $=$ f0W7qSIYh6-

9NqpL3gucqSKy5nbsIEtWDeZP-

xDfwtnIwsCpFNqcPnIekz0G7Tmbl75pS5ZJkKrl1tVnTCVxpk-

25bKzciRVWmjU asMwBh9R5dF99lD1FaRV9w85MIsaGobaCjQClGE5Dso p9Waih2GmutflpZO-wLRGCw-

CvHwGg3u90jehUjP NgH0Xhtf5aL tjSPKoFUPVIXiu849hCsG2HRUsbrX3i

2Jb8TeH9-

Y46olrm6lQDDcKx iYkYF8Ix6yZ2H 2D6ZiZeGf1j8k 1dVku8Mt-

J0irEdrKXmOg--

4HNJIN SzOZwQNkTMZ1f4ddipUPWNLEOUWrptQ_\&Key-Pair-

Id=APKAJLOHF5GGSLRBV4ZA

Balathandayutham, P., Sritharan, R., (2012), "A Study on Real Estate Marketing With Special Reference to Apartment Purchase", SELP Journal of Social Science 3 (12), 2012, 431-435. Retrieved from https://www.researchgate.net/profile/Balathandayutham-Dr-

P/publication/342901835_A_STUDY_ON_REAL_ESTATE_MARKETING_WIT H_SPECIAL_REFERENCE_TO_APARTMENT_PURCHASE/links/5f0c9d2f299 bf10744533d86/A-STUDY-ON-REAL-ESTATE-MARKETING-WITH-

SPECIAL-REFERENCE-TO-APARTMENT-PURCHASE.pdf

Balathandayutham, P., Sritharan, R., (2012), "Marketing Strategies for consumer house buying behaviour", Revitalising Global Business, 2012. 994-995.

Balathandayutham, P., Sritharan, R., (2013), "Service quality survey in apartment industry: a study on residential satisfaction among urban resident", IISRO Multi-conferences proceeding, 2013. Retrieved from https://www.researchgate.net/profile/Balathandayutham-Dr-

P/publication/342831707_Service_quality_survey_in_apartment_industry_ a_study_on_residential_satisfaction_among_urban_residents/links/5f07f40 2299bf188161026d8/Service-quality-survey-in-apartment-industry-astudy-on-residential-satisfaction-among-urban-residents.pdf

Balathandayutham, P., Sritharan, R., (2013), "A Focus on Factors Influencing Residential Satisfaction", Review Journal of Philosophy and Social Science 38 (2), 2013, 123-132. Retrieved from https://www.researchgate.net/profile/Balathandayutham-DrP/publication/342901892_A_FOCUS_ON_FACTORS_INFLUENCING_RESIDE NTIAL_SATISFACTION/links/5f0ca663a6fdcca32ae69b16/A-FOCUS-ONFACTORS-INFLUENCING-RESIDENTIAL-SATISFACTION.pdf

Balathandayutham, P., Sritharan, R., (2013), "A Study on Role of Management Graduate's Services in Real Estate Business", M.S.R Journal of Management 1 (2), 2013, 116-118. Retrieved from https://www.researchgate.net/profile/Balathandayutham-DrP/publication/342902040_A_STUDY_ON_ROLE_OF_MANAGEMENT_GRAD UATE'S_SERVICES_IN_REAL_ESTATE_BUSINESS/links/5f0ca33fa6fdcca32a e69a51/A-STUDY-ON-ROLE-OF-MANAGEMENT-GRADUATES-SERVICES-

IN-REAL-ESTATE-BUSINESS.pdf

Balathandayutham, P., Sritharan, R., (2013), "Detailed investigation of residential satisfaction in apartment's management service", International journal of research in commerce, it \& management 3 (09), 2013

Balathandayutham, P., Sritharan, R., (2013), "Residential Satisfaction : An Empirical Study With Special Focus on Flat Purchase", International Journal of Applied Management Research 5 (special issue 2013), 64-67. 
Balathandayutham, P., Sritharan, R., (2014), "A Study on the Residential Satisfaction among the Elderly in Chennai", International Journal of Research in Management Studies (IJRMS) 6 (1), 2014, 6-9. Retrieved from https://www.researchgate.net/profile/Balathandayutham-Dr-

P/publication/342902091_A_study_on_the_residential_satisfaction_among _the_elderly_in_Chennai/links/5f0cacbe92851c38a51a6a3e/A-study-onthe-residential-satisfaction-among-the-elderly-in-Chennai.pdf

Balathandayutham, P., Sritharan, R., (2014), "A study on the influence of service quality on Apartment Satisfaction in Chennai, Tamilandu", Bonfring International Journal of Industrial Engineering and Management, 2014

Balathandayutham, P., Sritharan, R., (2014), "Factorial Study on Residential Satisfaction of Apartment Residents", Sankhya International Journal of Management and Technology 3 (II (a)), 2014, 79-80. Retrieved from https://www.researchgate.net/profile/Balathandayutham-Dr-

P/publication/342834895_FACTORIAL_STUDY_ON_RESIDENTIAL_SATISF

ACTION_OF_APARTMENT_RESIDENTS/links/5f08618445851550509a35b a/FACTORIAL-STUDY-ON-RESIDENTIAL-SATISFACTION-OF-APARTMENTRESIDENTS.pdf

Balathandayutham, P., (2018), "A Study on the Satisfaction of the Elderly People in Apartment Culture", International Journal of Management Studies, Vol.-V, Issue $\quad-1(3), \quad 2018 . \quad 145-150 . \quad$ Retrieved from https://www.researchgate.net/profile/Balathandayutham-Dr-

P/publication/342902083_A_Study_on_the_Satisfaction_of_the_Elderly_Peo ple_in_Apartment_Culture/links/5f0cab074585155a55257b7c/A-Studyon-the-Satisfaction-of-the-Elderly-People-in-Apartment-Culture.pdf

Isabelina Nahmens (2009), Discovering the variables that influence new homebuyer service satisfaction, International Journal of Consumer Studies, Vol. 33 pp. 581-590. Retrieved from https://onlinelibrary.wiley.com/doi/abs/10.1111/j.14706431.2009.00801.x

Karl (1998), The Behavior of Home Buyers in Boom and Post-Boom Markets, New india economic review, pp. 29-46. Retrieved from https://www.nber.org/papers/w2748

Madavan, K., \& Vethirajan, C., (2019) "Analysis of customer satisfaction and postusage behaviour towards ATM services of private sector banks in Puducherry region". 2019.

Madavan, K., \& Vethirajan, C., (2020) "Customer Satisfaction on E-Banking Services of Public and Private Sector Banks in Puducherry Region -An Empirical Analysis". 11. 649-664. 10.34218/IJM.11.6.2020.054, 2020. Retrieved from https://www.researchgate.net/profile/Vethirajanc/publication/342465585_Customer_Satisfaction_on_E-

Banking_Services_of_Public_and_Private_Sector_Banks_in_Puducherry_Regi on_-

An_Empirical_Analysis/links/5f0577d992851c52d62076b5/CustomerSatisfaction-on-E-Banking-Services-of-Public-and-Private-Sector-Banks-inPuducherry-Region-An-Empirical-Analysis.pdf

Madavan, K., \& Vethirajan, C., (2020) "The Impact Of Electronic Banking Services On The Public And Private Sector Banks In Puducherry Region". Aegaeum. 8. 1046-1056, 2020. Retrieved from https://www.researchgate.net/profile/Vethirajanc/publication/342378730_THE_IMPACT_OF_ELECTRONIC_BANKING_SEVI 
CES_ON_THE_PUBLIC_AND_PRIVATE_SECTOR_BANKS_IN_PUDUCHERRY_R EGION/links/5ef191a6a6fdcc73be96cea5/THE-IMPACT-OF-ELECTRONICBANKING-SEVICES-ON-THE-PUBLIC-AND-PRIVATE-SECTOR-BANKS-INPUDUCHERRY-REGION.pdf

Noorsidi (2008) SERVQUAL and high-rise building: An achievement,Faculty of geoinformation science \& engineering publications. Retrieved from www.utm.edu.my

P.Balathandayutham and K. Anandanatarajan (2020), Digital marketing through social networking sites (SNS): A field of digital empowerment, International Journal of Scientific \& Technology Research volume 9, issue 02, February 2020. 734-736. Retrieved from https://d1wqtxts1xzle7.cloudfront.net/63881032/11_Scopus_Digital_Mar keting_Through_Social_Networking_Sites_Digital_Marketing_Through_Socia l_Networking_Sites20200710-16342-iucef2-with-cover-pagev2.pdf?Expires $=1634284993 \&$ Signature $=$ ba2sOM0hDlUTkbwy4iuKUHr4 Wj1920Q6gEhPOBnnaubo7iFze4vHILzQENuSCpfU xQGJ90wYLpn1449u QpjaoQnzHUbA4YvUcxhZGt65tfrnwDb05t H RyunBbOgQSQoen3RsqB0g 〜-

oMSmq36g4KRh13USBArUIdACdIM6Wo0399kf3dAeZ1rxsPtbBdos4BjH7f A24pPyKCMsI23H-

LOAwBATGbnqYOyxHFXeFEb72UZwJ2yf20Z8m0mfE1b3u8l 1bSrcLLD4 AmtLG8WuvVmreSsvClkpReuU cl4iBb336Bl T7eWJH9bENr7qLzg7Z3FS zbx-b1KOIi7-Sw_\&Key-Pair-Id=APKAJLOHF5GGSLRBV4ZA

Parasuraman, Zeithaml, V. and Berry, L. (1988), "SERVQUAL: a multiple-item scale for measuring consumer perceptions of quality", Journal of Retailing, 64,(1), pp. 12-40.

Rajakumar, C, S., Anandanatarajan, K., (2009) "Guest perception on service quality a study with reference to hotel industry", in journal of Asian business management 1 (1), 139-146.

Rajakumar, C, S., Anandanatarajan,. K., (2008) "Satisfaction and Image as the predictors of customer loyalty - An Empirical study in hotel industry", In Annamalai University Humanities Journal 45, 341 - 354.

Reijo savolinen (2009). The information needs of prospective homebuyers: an exploratory study of apartment purchases in Finland, Inter. Journal of Cons. Stud., Vol 33, pp 566-571,

Siamak (2011) Environmental quality as an important dimension of customer satisfaction in apartment industry, African Journal of Business Management Vol.5(17),pp.7272-7283

Vethirajan, C., (2018) "Impact of Supply Chain Management - Service Quality Strategies for Gaining Competitive Advantage", In NXT GEX Logistics Management 4.0 Pg- 76-81. ISBN No: 978-0-6482502-1-0.

Vethirajan, C., (2018) "Impact of Supply Chain Management - Service Quality Strategies for Gaining Competitive Advantage", In NXT GEX Logistics Management 4.0 Pg- 76-81. ISBN No: 978-0-6482502-1-0.

Vethirajan, C., (2018) "Modern Banking Services in India - A key tool for Indian Banking Sectors". In DBJC - Journal of Business Research, Jain Spire. National Business Research Conference on "Emerging trends in Commerce and management in the present decade" Pg 366-370 ISSN: 2248-9711.

Vethirajan, C., (2018) "Modern Banking Services in India - A key tool for Indian Banking Sectors". In DBJC - Journal of Business Research, Jain Spire. National 
Business Research Conference on "Emerging trends in Commerce and management in the present decade" Pg 366-370 ISSN: 2248-9711.

Vethirajan. C., (2016) "Insurance Services and Consumer Protection" National Seminar on Consumer Protection and empowerment in India - In ISBN No: 978-81-928690-1-8.

Vethirajan. C., (2017) "User's Opinion on Efficiency of Internet Financial Reporting Practices - A Study with reference to Karaikudi Town", In Paripex- Indian Journal of Research, Vol: 6, Issue:7, July 2017, PP: 18-20. ISSN: 2250-1991, UGC Approved journal (Sr.47432), Index Copernicus IC Value: 79.96, Journal, Impact Factor: 5.761. Retrieved from https://doi.org/10.15373/22501991

Vidhya, K., Rajakumar, C, S., (2014)"An empirical study on perceived service quality and patient satisfaction with special reference to Puducherry hospitals", in Asia Pacific Journal of Research, vol: 1 issue xiv

Vidhya, K., Rajakumar, C, S., (2015)"Emotional attachment and its impact on perceived service quality and patient satisfaction in Puducherry hospitals", in Asia Pacific Journal of Research, vol: 1. issue xxxi. Retrieved from https://web.archive.org/web/20180426044729id_/http://www.apjor.co m/downloads/0610201512.pdf

Vidhya, K.. Rajakumar, C, S., Jyothi, K, T., (2013) "An Empirical Study on Patient Delight and the Impact of Human and non Human Factor of service quality on Patient satisfaction in Private Hospitals", in Journal of Business and Management, 20-27. Retrieved from https://d1wqtxts1xzle7.cloudfront.net/32138500/D01242027.pdf?13824 $84800=\&$ response-content -

disposition=inline $\% 3 B+$ filename $\% 3 D D 01242027$.pdf\&Expires $=16345351$ 93\&Signature $=$ WMnsEUZkthBTM66oUz hPYJobtHFnDjW93UmOqhkWxe $\sim$ V5he9vRv3bboJx0h5fZMt $\sim$ kgnF5xpYSW4uUHRgczntJnUXBINZXiAyo1KAc4eGJUNPdolUIF9WvN-

Rs4hVKeBjWJVfENhTub z74qez9lpF6qW4SfInkypVx6AG1e3cvgaEDgByzJ BmzGINNDaI5GDynSYb Ysb3ygUiqS9t QaWdAFrR8dxHImGofAMRy4ubq 6X HMj8NdVmgkAWNcIL76mCH0x-OvLzND2IpYAjd9pndxqrlkGWisSJe7HniP1voftaygkPs453wwjQT1JsNInSqCh9bnaTT kcBlg \& \&ey-Pair-Id=APKAJLOHF5GGSLRBV4ZA

Yao-chen Kuo (2011) Elucidating how service quality constructs influence resident satisfaction with condominium management, Expert Sys. with Appl. Vol. 38, pp. 5755-5763. Retrieved
https://doi.org/10.1016/j.eswa.2010.10.057 from 